\title{
Cation Involvement in Telomestatin Binding to G-Quadruplex DNA
}

\author{
Frédéric Rosu, ${ }^{1,2}$ Valérie Gabelica, ${ }^{1,2}$ Nicolas Smargiasso, ${ }^{1,2}$ Gabriel Mazzucchelli,, ${ }^{1,2}$ \\ Kazuo Shin-Ya, ${ }^{3}$ and Edwin De Pauw ${ }^{1,2}$
}

\author{
${ }^{1}$ Mass Spectrometry Laboratory, Department of Chemistry, University of Liège, 4000 Liège, Belgium \\ ${ }^{2}$ GIGA-Systems Biology and Chemical Biology, University of Liège, 4000 Liège, Belgium \\ ${ }^{3}$ Biomedicinal Information Research Center, Biological Systems Control Team, \\ National Institute of Advanced Industrial Science and Technology, Tokyo 135-0064, Japan
}

Correspondence should be addressed to Valérie Gabelica, v.gabelica@ulg.ac.be

Received 1 February 2010; Accepted 13 April 2010

Academic Editor: Daniela Montesarchio

Copyright ( $) 2010$ Frédéric Rosu et al. This is an open access article distributed under the Creative Commons Attribution License, which permits unrestricted use, distribution, and reproduction in any medium, provided the original work is properly cited.

\begin{abstract}
The binding mode of telomestatin to G-quadruplex DNA has been investigated using electrospray mass spectrometry, by detecting the intact complexes formed in ammonium acetate. The mass measurements show the incorporation of one extra ammonium ion in the telomestatin complexes. Experiments on telomestatin alone also show that the telomestatin alone is able to coordinate cations in a similar way as a crown ether. Finally, density functional theory calculations suggest that in the G-quadruplextelomestatin complex, potassium or ammonium cations are located between the telomestatin and a G-quartet. This study underlines that monovalent cation coordination capabilities should be integrated in the rational design of G-quadruplex binding ligands.
\end{abstract}

\section{Introduction}

The formation of G-quadruplex folds by telomeric DNA is thought to play a role in telomere regulation. It has been shown that G-quadruplex ligands binding specifically to the telomeric G-quadruplex structure effectively alter telomere capping and cause the senescence or apoptosis of cancer cells [1-5]. A variety of ligands have now been described as Gquadruplex binders, but a key issue in ligand design is often the specificity for G-quadruplexes over duplex sequences [4, 6-8]. Identifying binding modes that make a ligand a specific and highly active G-quadruplex binder is crucial for the rational design of novel molecules.

Telomestatin (Figure 1) is one of the most emblematic G-quadruplex ligands. The molecule was first extracted from Streptomyces anulatus 3533-SV4 [9]. It is highly specific for G-quadruplexes, with no significant binding to duplexes [10-12]. Telomestatin was found to effectively inhibit the DNA binding of telomere-associated proteins such as telomerase [13], POT1 and TRF2 [14], and even
Topo III in ALT cell lines [15]. It therefore induces telomere shortening and apoptosis [16-19] not only via telomerase inhibition but also via telomere uncapping, and therefore has potential activity against many cancer cell types.

Telomestatin binds to G-quadruplexes, among which is the human telomeric G-quadruplex, by external stacking [12]. One G-quadruplex unit can therefore accommodate two telomestatin ligands, one on each end. A recent modeling study showed that telomestatin has a tendency to capture a potassium ion, either from the G-quadruplex itself or from the solution [20]. Here we show that mass spectrometry provides experimental evidence for the accommodation of one extra cation when a telomestatin molecule is bound to a G-quadruplex. This will be illustrated for three typical Gquadruplexes: the tetramolecular $\left[\mathrm{TG}_{4} \mathrm{~T}\right]_{4}$ quadruplex, the 4-repeat telomeric sequence $\left(\mathrm{T}_{2} \mathrm{AG}_{3}\right)_{4}$, and the Pu22myc promoter sequence $\mathrm{GAG}_{3} \mathrm{TG}_{4} \mathrm{AG}_{3} \mathrm{TG}_{4} \mathrm{~A}_{2} \mathrm{G}$. The typical folds adopted by each of these three G-quadruplexes in ammonium acetate were studied previously [21-23] and are summarized in Figure 1. 


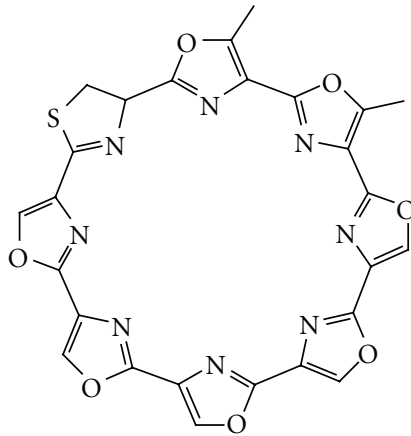

Telomestatin

(a)

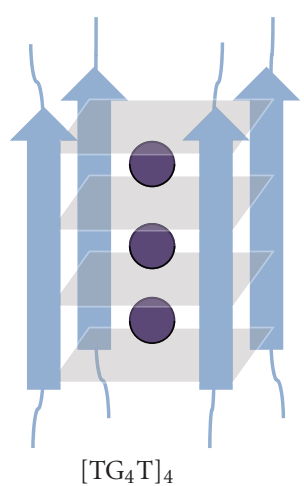

(b)

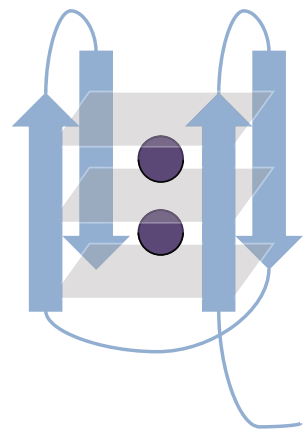

Telo4: $\left(\mathrm{T}_{2} \mathrm{AG}_{3}\right)_{4}$

(c)

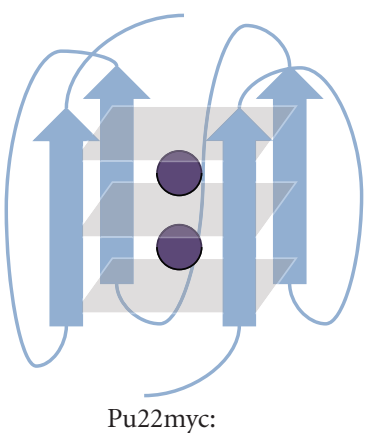

$\mathrm{GAG}_{3} \mathrm{TG}_{4} \mathrm{AG}_{3} \mathrm{TG}_{4} \mathrm{~A}_{2} \mathrm{G}$

(d)

Figure 1: Chemical structure of telomestatin and folding pattern of the three G-quadruplexes studied here. $\left[\mathrm{TG}_{4} \mathrm{~T}\right]_{4}$ adopts a parallel fold and can incorporate three ammonium ions between its four G-quartets [21], the 4-repeat telomeric sequence $\left(\mathrm{T}_{2} \mathrm{AG}_{3}\right)_{4}$ adopts an intramolecular antiparallel fold in ammonium acetate and incorporates up to two ammonium ions [22], and the Pu22myc promoter sequence $\mathrm{GAG}_{3} \mathrm{TG}_{4} \mathrm{AG}_{3} \mathrm{TG}_{4} \mathrm{~A}_{2} \mathrm{G}$ adopts a predominantly parallel fold in ammonium acetate and incorporates two ammonium ions [23].

\section{Experimental Section}

2.1. Materials. All oligonucleotides were purchased from Eurogentec (Seraing, Belgium), solubilized in water doubly distilled in house, and the $400 \mu \mathrm{M}$ stock solutions were stored at $-20^{\circ} \mathrm{C}$. The solvents used include methanol (absolute, HPLC grade, Biosolve, Valkenswaard, The Netherlands), bidistilled water, and aqueous ammonium acetate (5 M stock solution from Fluka, diluted with bi-distilled water). $\mathrm{KCl}$ for the evaluation of the complexation of telomestatin alone was puriss, p.a., $\geq 99.5 \%$ (T) (Fluka). G-quadruplexes were formed by annealing (heating the oligonucleotides for 5 minutes at $85^{\circ} \mathrm{C}$, followed by slow cooling to room temperature) in $150 \mathrm{mM}$ ammonium acetate. The G-quadruplexforming oligonucleotides were $\mathrm{dTG}_{4} \mathrm{~T}$ (annealed at $200 \mu \mathrm{M}$ single strand to form $50 \mu \mathrm{M}$ tetramolecular G-quadruplex); the telomeric sequence $\left(\mathrm{T}_{2} \mathrm{AG}_{3}\right)_{4}$ and the $\mathrm{Pu} 22$ myc promoter sequence $\mathrm{GAG}_{3} \mathrm{TG}_{4} \mathrm{AG}_{3} \mathrm{TG}_{4} \mathrm{~A}_{2} \mathrm{G}$ (annealed at $50 \mu \mathrm{M}$ single strand to form intramolecular G-quadruplexes). Telomestatin was isolated and purified as described elsewhere $[9,24]$ to obtain a $1 \mathrm{mM}$ stock solution in DMSO. For the electrospray mass spectrometry analysis of the complexes, the final injected solutions were $5 \mu \mathrm{M}$ in G-quadruplex and 5 to $10 \mu \mathrm{M}$ in telomestatin (only $10 \mu \mathrm{M}$ results are shown), in 80/20 (v/v) aqueous ammonium acetate $(150 \mathrm{mM}) /$ methanol.

2.2. Mass Spectrometry. Electrospray mass spectrometry experiments were performed on a Q-TOF Ultima Global (Waters, Manchester, UK). The spectra of the intact G-quadruplexes and their noncovalent complexes with telomestatin were recorded in the negative ion mode (capillary voltage $=-2.2 \mathrm{~V}$, source and desolvation temperatures $=70^{\circ} \mathrm{C}$, cone $=100 \mathrm{~V}$, RF Lens1 Energy $=$ $45 \mathrm{~V}$, source pirani pressure $=3.94 \mathrm{mbar}$, collision energy $=10 \mathrm{~V}$ ), smoothed (mean function, $3 \times 20$ channels) and subtracted (polynomial order 99, $0.1 \%$ below curve). The spectra of telomestatin in the absence of G-quadruplex were recorded in the positive ion mode (capillary voltage $=+2.8 \mathrm{~V}$, source and desolvation temperatures $=80$ and $100^{\circ} \mathrm{C}$, resp., cone $=100 \mathrm{~V}$, RF Lens 1 Energy $=50 \mathrm{~V}$, source pirani pressure $=3.33 \mathrm{mbar}$ and collision energy $=7 \mathrm{~V}$ ) and were not subjected to smoothing or background subtraction.

2.3. Calculations. For the [telomestatin + cation] binary complexes, the ammonium, potassium, and sodium cations were manually docked within the telomestatin ring, and the resulting structures were optimized using density functional theory (DFT) with the hybrid functional B3LYP and the 6-31G(d,p) basis set. For the ternary complexes between [telomestatin + cation + one G-quartet], the telomestatin was manually docked on top of an optimized structure of a G-quartet coordinated with the cation (ammonium, potassium, sodium). The ternary complexes were then optimized using DFT B3LYP at the 6-31G(d,p) level. All electronic structure calculations were performed using the Gaussian 03 rev. D.02 software suite [25]. Comparison with a larger basis set $(6-311+G(d, p))$ was performed for one of the complexes (G-tetrad $+\mathrm{K}+$ telomestatin), and the results were similar in terms of both energies $(0.8 \mathrm{kcal} / \mathrm{mol})$ and geometries (RMSD 0.16 ̊). 6-31G(d,p) basis set was therefore used for all calculations. Other hybrid functional BHandHLYP and new meta-GGA hybrid MPWB1K [26] have also been tested for comparison with B3LYP.

\section{Results and Discussion}

When operated in soft source conditions, electrospray mass spectrometry allows detecting intact noncovalent complexes [27-30]. In the analysis of quadruplex-ligand complexes, it therefore allows determining the number of strands, the number of ligands, and the number of cations in each complex. Electrospray mass spectrometry of nucleic acid noncovalent complexes is typically performed in ammonium acetate solution in order to obtain clean spectra [31]. Ammonium ions present in the counter-ion shell around phosphates are lost during the final stages of desolvation in the electrospray source, even in soft conditions 


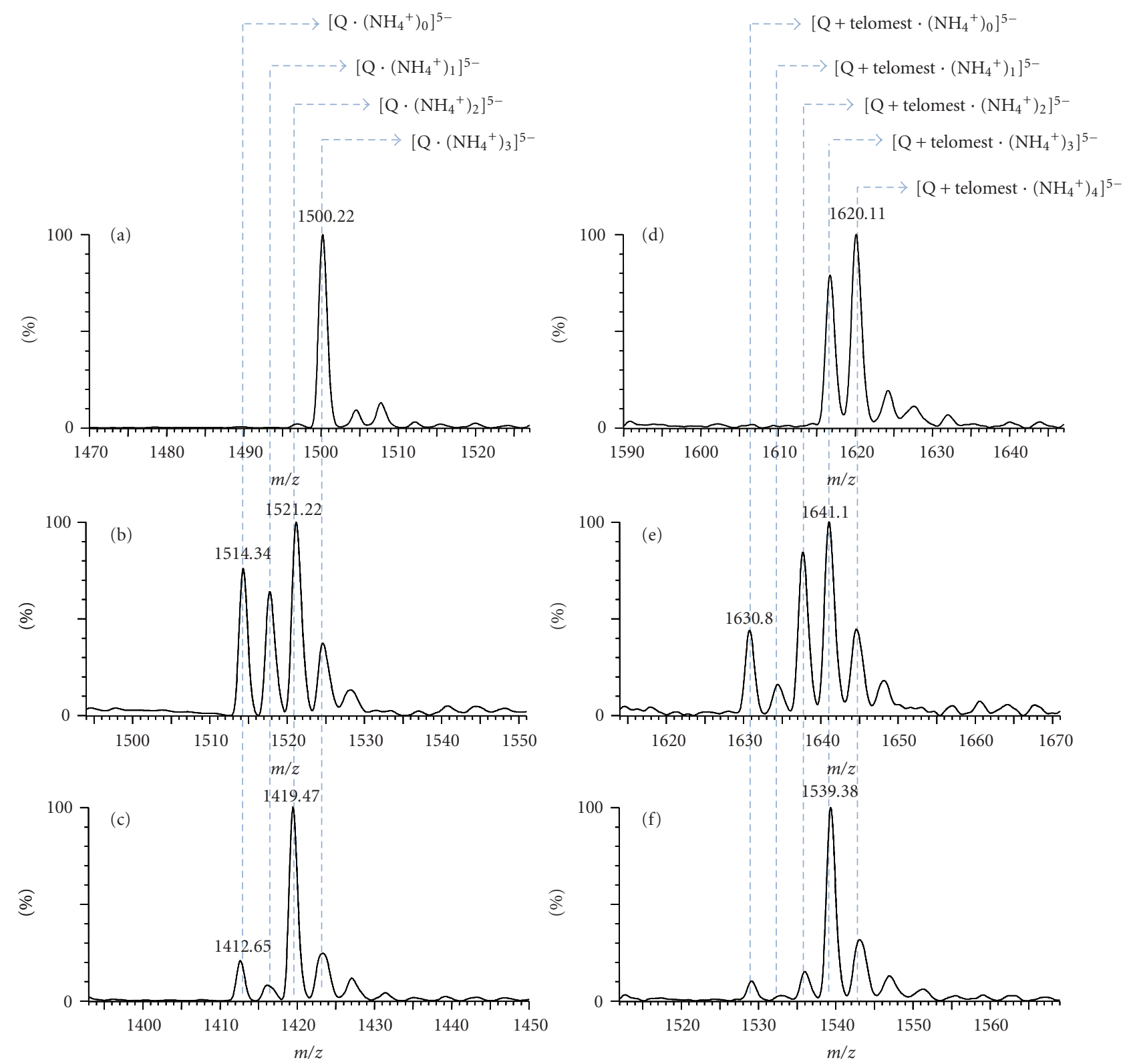

FIGURE 2: Negative ion mode electrospray mass spectra of mixtures of $10 \mu \mathrm{M}$ telomestatin and $5 \mu \mathrm{M}$ of G-quadruplexes. Zooms on the peaks of free G-quadruplex (a) $\left[\mathrm{TG}_{4} \mathrm{~T}\right]_{4}$, (b) telomeric sequence $\left(\mathrm{T}_{2} \mathrm{AG}_{3}\right)_{4}$, and (c) Pu22 myc promoter sequence $\mathrm{GAG}_{3} \mathrm{TG}_{4} \mathrm{AG}_{3} \mathrm{TG}_{4} \mathrm{~A}_{2} \mathrm{G}$, and on the complexes between (d) one telomestatin and $\left[\mathrm{TG}_{4} \mathrm{~T}\right]_{4},(\mathrm{e})$ one telomestatin and $\left(\mathrm{T}_{2} \mathrm{AG}_{3}\right)_{4}$, and (f) one telomestatin and $\mathrm{GAG}_{3} \mathrm{TG}_{4} \mathrm{AG}_{3} \mathrm{TG}_{4} \mathrm{~A}_{2} \mathrm{G}$. The spectra were recorded from and $80 / 20$ aqueous ammonium acetate $(150 \mathrm{mM}) / \mathrm{methanol}$ solution, using soft source conditions to preserve the specifically bound ammonium ions.

(low acceleration voltages). In contrast, ammonium ions bound sufficiently tightly to the G-quadruplex, such as the ammonium ions trapped between the G-quartets, will persist at higher acceleration voltages in the source than the nonspecifically bound ones [21].

Figure 2 shows the electrospray mass spectra of three typical G-quadruplexes: (a) $\left[\mathrm{TG}_{4} \mathrm{~T}\right]_{4}$, (b) the telomeric sequence $\left(\mathrm{T}_{2} \mathrm{AG}_{3}\right)_{4}$, and (c) the Pu22myc promoter sequence $\mathrm{GAG}_{3} \mathrm{TG}_{4} \mathrm{AG}_{3} \mathrm{TG}_{4} \mathrm{~A}_{2} \mathrm{G}$ and on their $1: 1$ complexes with telomestatin (d-f, resp.). The injected mixtures are $5 \mu \mathrm{M}$ in each G-quadruplex $10 \mu \mathrm{M}$ in telomestatin, in $80 / 20$ aqueous ammonium acetate $(150 \mathrm{mM}) /$ methanol, and the spectra were recorded using soft source conditions to preserve the specifically bound ammonium ions. The free $\left[\mathrm{TG}_{4} \mathrm{~T}\right]_{4}$ Gquadruplex (Figure 2(a)) contains three ammonium ions: the 5- charge state is found at $m / z=1500.22$, corresponding to $\left[\mathrm{Q} \cdot\left(\mathrm{NH}_{4}^{+}\right)_{3}\right]^{5-}$. The major peaks of the telomeric (Figure 2(b)) and Pu22myc (Figure 2(c)) G-quadruplexes at charge state 5- are corresponding to the intramolecular Gquadruplex with two ammonium ions, at $(\mathrm{m} / \mathrm{z})=1521.22$ and 1419.47, respectively. For the charge state $z=5$, with the average mass of telomestatin being $m=582.5 \mathrm{Da}$, the 


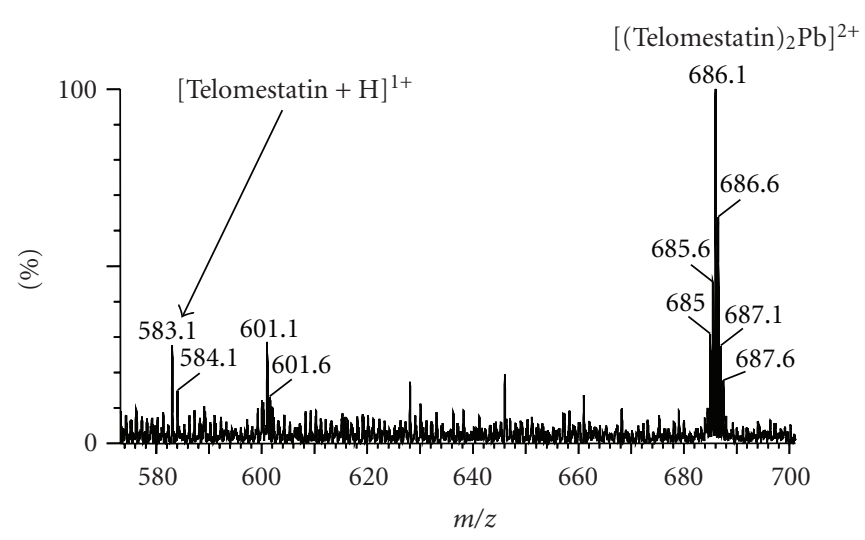

(a)

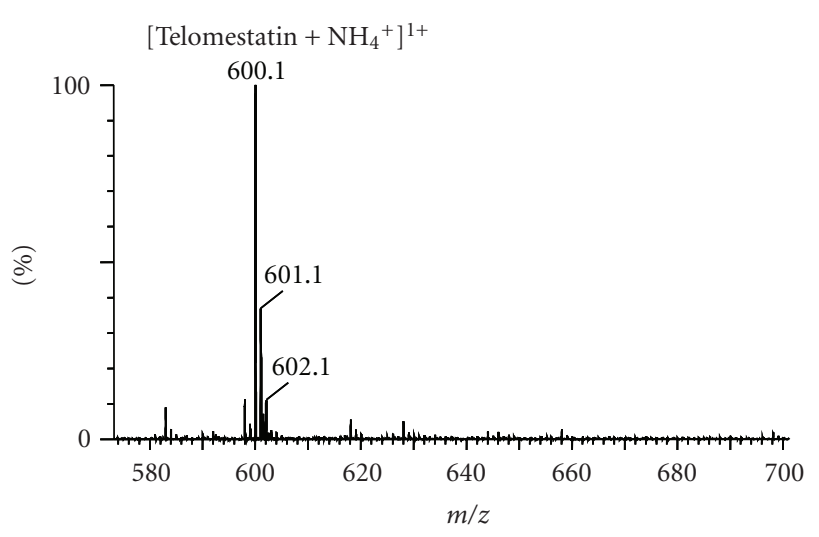

(b)

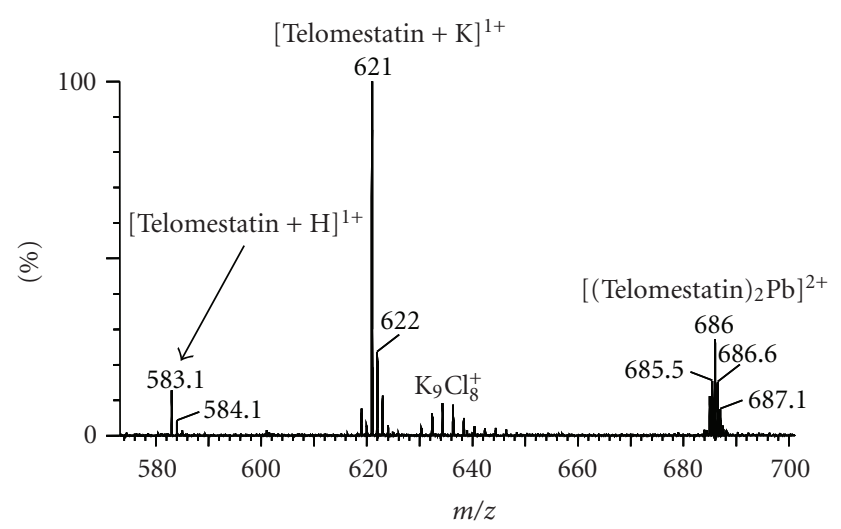

(c)

Figure 3: Positive ion mode electrospray mass spectra of $15 \mu \mathrm{M}$ telomestatin (a) in 80/20 water/methanol, (b) in 80/20 water methanol and $5 \mu \mathrm{M}$ ammonium acetate, and (c) in $80 / 20$ water methanol and $5 \mu \mathrm{M}$ potassium chloride.

$\Delta(m / z)$ between the G-quadruplex and its complex with one telomestatin, with no change in the amount of ammonium ions incorporated, is expected to be equal to $582.5 / 5=$ 116.5. In contrast, the observed $\Delta(\mathrm{m} / z)$ between the major peak of the quadruplex and the major peak of its complex with one ligand is equal to 119.9 (compare Figure 2(a) with Figure 2(d), and Figure 2(b) with Figure 2(e), Figure 2(c) with Figure 2(f)). This corresponds to the addition of one telomestatin molecule, one extra ammonium ion, and the subtraction of one proton for the charge balance $(119.9=$ $(585.5+18-1) / 5)$. The complex with one telomestatin ligand therefore systematically contains one more ammonium ion than the corresponding unbound G-quadruplex. This extra ammonium ion is lost when the acceleration voltage is increased.

In our previous report on the MS detection of telomestatin binding to telomeric DNA [11], we have missed this "extra ammonium" for two reasons. Firstly, for the 3.5repeat telomeric sequence studied previously it is difficult to preserve two inner ammoniums even in soft conditions. Secondly, soft conditions could not be used because a long duplex had to be detected simultaneously with the G-strand, and the electrospray source conditions were chosen as a compromise.
Electrospray mass spectrometry is also powerful to analyze caged supramolecular complexes such as crown ethers bound to cations [32-35]. To probe whether telomestatin is able to coordinate a cation already in the absence of G-quadruplex, we used ESI-MS in the positive ion mode on telomestatin solutions. Figure 3(a) shows the spectrum obtained with telomestatin dilution in bi-distilled water. The signal-to-noise ratio of all peaks is weak, indicating low protonation and cationization efficiencies. Surprisingly, we found that the major peak was a doubly charged ion at $\mathrm{m} / \mathrm{z}$ $=686.1$ (base peak), whose isotopic distribution matches with that of a complex between two telomestatin ligands and one lead ion adduct. The fragment ion spectrum shows the loss of one telomestatin, and the isotopic distribution of the resulting [Telomestatin $+\mathrm{Pb}$ ] complex confirms the presence of lead. Traces of lead come from the purification of telomestatin from Streptomyces anulatus 3533-SV4 [24]. Another weak doubly charged peak is tentatively assigned to a complex between two telomestatin and two $\mathrm{H}_{3} \mathrm{O}^{+}$ions, and the fragment ion spectrum shows only the singly protonated telomestatin.

We then doped the solution with either ammonium acetate or with potassium chloride, in substoichiometric amounts, to probe if telomestatin was able to coordinate 


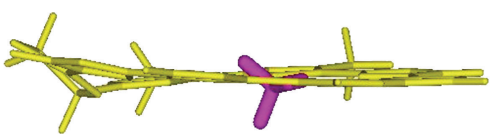

(a)
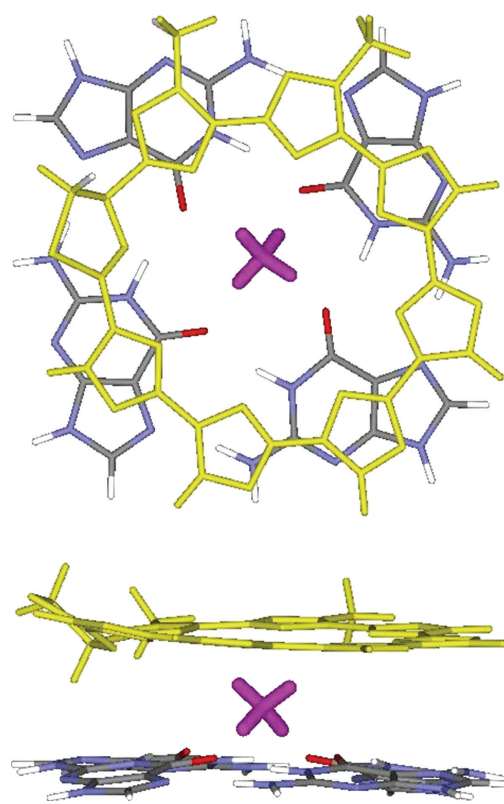

(d)

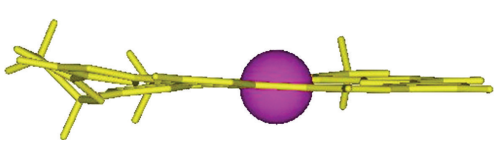

(b)
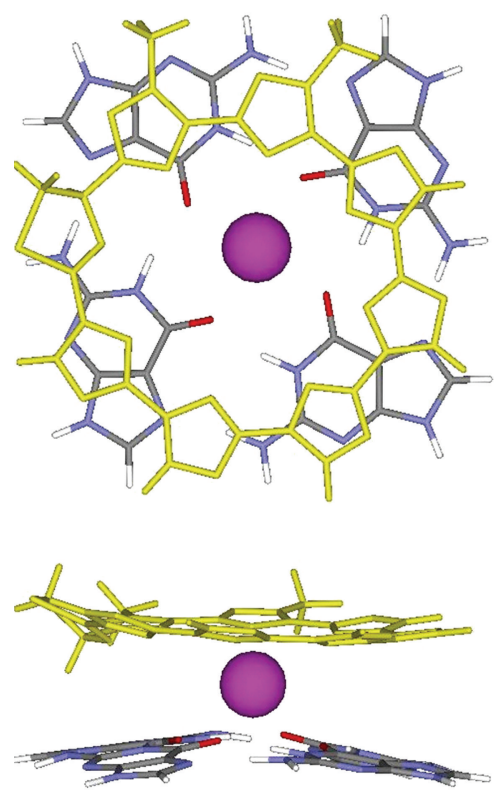

(e)

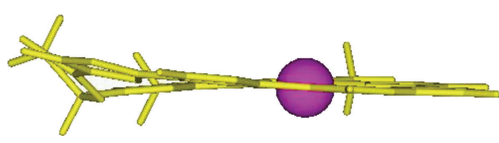

(c)
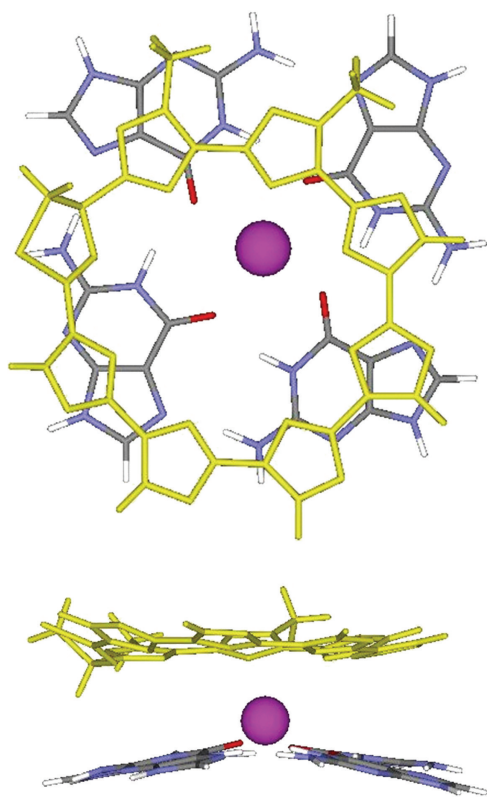

(f)

FIgure 4: Optimized geometries (DFT B3LYP, 6-31G(d,p)) of the telomestatin-cation complexes (side view) for (a) $\mathrm{NH}_{4}^{+}$, (b) $\mathrm{K}^{+}$, and (c) $\mathrm{Na}^{+}$, and optimized geometries of the telomestatin—cation-G-quartet complexes (top view and side view) for (d) $\mathrm{NH}_{4}^{+}$, (e) $\mathrm{K}^{+}$, and (f) $\mathrm{Na}^{+}$. Telomestatin is shown in yellow, the cation is shown in purple, and the G-quartet is colored by elements.

monovalent cations such as those typically coordinated to G-quartets. In the presence of ammonium ions, the lead complex totally disappears and the complex [telomestatin + $\mathrm{NH}_{4}^{+}$] is detected at $m / z=600$. In the presence of potassium ions, the complex [telomestatin $+\mathrm{K}^{+}$] is detected at $m / z=$ 621 , but the lead complex has not disappeared completely.

All experimental results suggest that telomestatin has significant affinity for monovalent cations like the ammonium ion, and this could influence its binding mode to the G-quadruplex DNA. We performed DFT calculations in order to ascertain the possible coordination geometries of the monovalent cations to telomestatin. The geometries of the [telomestatin + cation] binary complexes are shown in Figures 4(a)-4(c), and the geometries of the ternary complexes between [telomestatin + cation + one G-quartet] are shown in Figures 4(d)-4(f). In the isolated [telomestatin + cation] complexes, all cations are coordinated in the plane of the telomestatin. In the ternary complexes with the Gquartet, the cation clearly moves towards the G-quartet. The structures of the complexes with $\mathrm{K}^{+}$and $\mathrm{NH}_{4}^{+}$are similar, with the cation coordinated midway between the telomestatin and the G-quartet. Sodium, on the other hand, sits closer to the G-quartet than to the telomestatin.

The mode of cation coordination to the telomestatinG-quartet system is similar to the coordination mode already described for successive G-quartets [36]. In terms of coordination geometries, potassium tends to sit between
G-quartets while sodium tends to fit in the middle of one G-quartet because it is smaller. $\mathrm{K}^{+}$and $\mathrm{NH}_{4}^{+}$have similar ionic radii $[37,38]$ and therefore behave similarly, and the same trend is observed for our telomestatin-Gquartet complex. The optimized geometries are similar for all functionals tested (B3LYP, BHandHLYP, MPBW1K) (see Figure S1 in Supplementary Material available online at doi: 10.4061/2010/121259), with the cation in the plane of telomestatin in the absence of G-quartet, and between telomestatin and the G-quartet in the ternary complex. However, the functionals have a greater influence on the computed interaction energies. The root mean square distances (RMSDs) for two-by-two comparisons of hybrid functional, and the interaction energies of $\mathrm{NH}_{4}^{+}, \mathrm{K}^{+}$and $\mathrm{Na}^{+}$ with telomestatin alone, telomestatin + one $\mathrm{G}$-quartet are given in supplementary Tables S1 and S2, respectively.

\section{Conclusion}

We have therefore shown that telomestatin readily coordinates monovalent cations such as $\mathrm{K}^{+}$and $\mathrm{NH}_{4}^{+}$, and that telomestatin retains this cation while binding to Gquadruplexes. The observed stoichiometry and the calculations are consistent with a cation trapped midway between the telomestatin and the G-quartet. Telomestatin therefore acts like an analog of a G-quartet. This study underlines that monovalent cation coordination capabilities should be 
integrated in the rational design of G-quadruplex binding ligands.

\section{Acknowledgments}

The authors wish it to be known that, in their opinion, the first two authors should be regarded as joint first authors. This work was supported by the Fonds de la Recherche Scientifique (FNRS) (FRFC 2.4.623.05 to Edwin De Pauw, CC.1.5.286.09.F to Valérie Gabelica, research associate position to Valérie Gabelica, postdoctoral fellowship to Frédéric Rosu, and logistician fellowship to Nicolas Smargiasso), and by the University of Liége (starting Grant FRSD-08/10 to V.G.).

\section{References}

[1] E. M. Rezler, D. J. Bearss, and L. H. Hurley, "Telomere inhibition and telomere disruption as processes for drug targeting," Annual Review of Pharmacology and Toxicology, vol. 43, pp. 359-379, 2003.

[2] D. J. Bearss, L. H. Hurley, and D. D. Von Hoff, "Telomere maintenance mechanisms as a target for drug development," Oncogene, vol. 19, no. 56, pp. 6632-6641, 2000.

[3] S. M. Bailey and J. P. Murnane, "Telomeres, chromosome instability and cancer," Nucleic Acids Research, vol. 34, no. 8, pp. 2408-2417, 2006.

[4] S. Neidle, "The structures of quadruplex nucleic acids and their drug complexes," Current Opinion in Structural Biology, vol. 19, no. 3, pp. 239-250, 2009.

[5] P. Alberti, L. Lacroix, L. Guittat, C. Hélène, and J. L. Mergny, "Nucleic acids as targets for antitelomerase agents," Mini Reviews in Medicinal Chemistry, vol. 3, no. 1, pp. 23-36, 2003.

[6] D. Monchaud and M.-P. Teulade-Fichou, "A hitchhiker's guide to G-quadruplex ligands," Organic and Biomolecular Chemistry, vol. 6, no. 4, pp. 627-636, 2008.

[7] J.-F. Riou, D. Gomez, H. Morjani, and C. Trentesaux, "Quadruplex ligand recognition: biological aspects," in Quadruplex Nucleic Acids, S. Neidle and S. Balasubramanian, Eds., pp. 154-179, The Royal Soceity of Chemistry, Cambridge, UK, 2006.

[8] M. S. Searle and G. D. Balkwill, "DNA quadruplex-ligand recognition: structure and dynamics," in Quadruplex Nucleic Acids, S. Neidle and S. Balasubramanian, Eds., pp. 131-153, The Royal Soceity of Chemistry, Cambridge, UK, 2006.

[9] K. Shin-Ya, K. Wierzba, and K. Matsuo et al., "Telomestatin, a novel telomerase inhibitor from Streptomyces anulatus," Journal of the American Chemical Society, vol. 123, no. 6, pp. 1262-1263, 2001.

[10] A. De Cian, L. Guittat, K. Shin-Ya, J. F. Riou, and J. L. Mergny, "Affinity and selectivity of G4 ligands measured by FRET," Nucleic Acids Symposium Series, no. 49, pp. 235-236, 2005.

[11] F. Rosu, V. Gabelica, K. Shin-Ya, and E. De Pauw, "Telomestatin-induced stabilization of the human telomeric DNA quadruplex monitored by electrospray mass spectrometry," Chemical Communications, vol. 9, no. 21, pp. 2702-2703, 2003.

[12] M.-Y. Kim, H. Vankayalapati, K. Shin-Ya, K. Wierzba, and L. H. Hurley, "Telomestatin, a potent telomerase inhibitor that interacts quite specifically with the human telomeric intramolecular G-quadruplex," Journal of the American Chemical Society, vol. 124, no. 10, pp. 2098-2099, 2002.
[13] T. Tauchi, K. Shin-Ya, and G. Sashida et al., "Activity of a novel G-quadruplex-interactive telomerase inhibitor, telomestatin (SOT-095), against human leukemia cells: involvement of ATM-dependent DNA damage response pathways," Oncogene, vol. 22, no. 34, pp. 5338-5347, 2003.

[14] D. Gomez, T. Wenner, and B. Brassart et al., "Telomestatininduced telomere uncapping is modulated by POT1 through G-overhang extension in HT1080 human tumor cells," Journal of Biological Chemistry, vol. 281, no. 50, pp. 38721-38729, 2006.

[15] N. Temime-Smaali, L. Guittat, A. Sidibe, K. Shin-Ya, C. Trentesaux, and J.-F. Riou, "The G-quadruplex ligand telomestatin impairs binding of topoisomerase III $\alpha$ to G-quadruplexforming oligonucleotides and uncaps telomeres in ALT cells," PLoS ONE, vol. 4, no. 9, article e6919, 2009.

[16] T. Tauchi, K. Shin-Ya, and G. Sashida et al., "Telomerase inhibition with a novel G-quadruplex-interactive agent, telomestatin: in vitro and in vivo studies in acute leukemia," Oncogene, vol. 25, no. 42, pp. 5719-5725, 2006.

[17] N. Binz, T. Shalaby, P. Rivera, K. Shin-Ya, and M. A. Grotzer, "Telomerase inhibition, telomere shortening, cell growth suppression and induction of apoptosis by telomestatin in childhood neuroblastoma cells," European Journal of Cancer, vol. 41, no. 18, pp. 2873-2881, 2005.

[18] M. Sumi, T. Tauchi, and G. Sashida et al., "A G-quadruplexinteractive agent, telomestatin (SOT-095), induces telomere shortening with apoptosis and enhances chemosensitivity in acute myeloid leukemia," International Journal of Oncology, vol. 24, no. 6, pp. 1481-1487, 2004.

[19] M. A. Shammas, R. J. Shmookler Reis, and C. Li et al., "Telomerase inhibition and cell growth arrest after telomestatin treatment in multiple myeloma," Clinical Cancer Research, vol. 10, no. 2, pp. 770-776, 2004.

[20] S. Agrawal, R. P. Ojha, and S. Maiti, "Energetics of the human Tel-22 quadruplex-telomestatin interaction: a molecular dynamics study," Journal of Physical Chemistry B, vol. 112, no. 22, pp. 6828-6836, 2008.

[21] F. Rosu, V. Gabelica, C. Houssier, P. Colson, and E. De Pauw, "Triplex and quadruplex DNA structures studied by electrospray mass spectrometry," Rapid Communications in Mass Spectrometry, vol. 16, no. 18, pp. 1729-1736, 2002.

[22] E. S. Baker, S. L. Bernstein, V. Gabelica, E. De Pauw, and M. T. Bowers, "G-quadruplexes in telomeric repeats are conserved in a solvent-free environment," International Journal of Mass Spectrometry, vol. 253, no. 3, pp. 225-237, 2006.

[23] V. Gabelica, E. S. Baker, M.-P. Teulade-Fichou, E. De Pauw, and M. T. Bowers, "Stabilization and structure of telomeric and c-myc region intramolecular G-quadruplexes: the role of central cations and small planar ligands," Journal of the American Chemical Society, vol. 129, no. 4, pp. 895-904, 2007.

[24] H. Seto, K. Shin-Ya, and K. Wierzba, "Substance GM-95, process for producing the same and utilization thereof," WO 00/24747, October 1999.

[25] Gaussian 03, Revision D.02, Gaussian, Wallingford, Conn, USA, 2004.

[26] Y. Zhao and D. G. Truhlar, "How well can new-generation density functional methods describe stacking interactions in biological systems?" Physical Chemistry Chemical Physics, vol. 7, no. 14, pp. 2701-2705, 2005.

[27] K. Breuker, "New mass spectrometric methods for the quantification of protein-ligand binding in solution," Angewandte Chemie - International Edition, vol. 43, no. 1, pp. 22-25, 2003. 
[28] M. M. Siegel, "Early discovery drug screening using mass spectrometry," Current Topics in Medicinal Chemistry, vol. 2, no. 1, pp. 13-33, 2002.

[29] B. N. Pramanik, P. L. Bartner, U. A. Mirza, Y.-H. Liu, and A. K. Ganguly, "Electrospray ionization mass spectrometry for the study of non-covalent complexes: an emerging technology," Journal of Mass Spectrometry, vol. 33, no. 10, pp. 911-920, 1998.

[30] J. A. Loo, "Studying noncovalent protein complexes by electrospray ionization mass spectrometry," Mass Spectrometry Reviews, vol. 16, no. 1, pp. 1-23, 1997.

[31] F. Rosu, E. De Pauw, and V. Gabelica, "Electrospray mass spectrometry to study drug-nucleic acids interactions," Biochimie, vol. 90, no. 7, pp. 1074-1087, 2008.

[32] C. A. Schalley, "Molecular recognition and supramolecular chemistry in the gas phase," Mass Spectrometry Reviews, vol. 20, no. 5, pp. 253-309, 2001.

[33] E. Leize, A. Jaffrezic, and A. Van Dorsselaer, "Correlation between solvation energies and electrospray mass spectrometric response factors. Study by electrospray mass spectrometry of supramolecular complexes in thermodynamic equilibrium in solution," Journal of Mass Spectrometry, vol. 31, no. 5, pp. 537-544, 1996.

[34] S. M. Blair, J. S. Brodbelt, A. P. Marchand, K. A. Kumar, and H.-S. Chong, "Evaluation of binding selectivities of caged crown ligands toward heavy metals by electrospray ionization/quadrupole ion trap mass spectrometry," Analytical Chemistry, vol. 72, no. 11, pp. 2433-2445, 2000.

[35] E. C. Kempen, J. S. Brodbelt, R. A. Bartsch, Y. Jang, and J. S. Kim, "Investigation of alkali metal cation selectivities of lariat ethers by electrospray ionization mass spectrometry," Analytical Chemistry, vol. 71, no. 24, pp. 5493-5500, 1999.

[36] J. Gu and J. Leszczynski, "Origin of $\mathrm{Na}^{+} / \mathrm{K}^{+}$selectivity of the guanine tetraplexes in water: the theoretical rationale," Journal of Physical Chemistry A, vol. 106, no. 3, pp. 529-532, 2002.

[37] N. V. Hud, P. Schultze, V. Sklenář, and J. Feigon, "Binding sites and dynamics of ammonium ions in a telomere repeat DNA quadruplex," Journal of Molecular Biology, vol. 285, no. 1, pp. 233-243, 1999.

[38] P. Schultze, N. V. Hud, F. W. Smith, and J. Feigon, "The effect of sodium, potassium and ammonium ions on the conformation of the dimeric quadruplex formed by the Oxytricha nova telomere repeat oligonucleotide d(G4T4G4)," Nucleic Acids Research, vol. 27, no. 15, pp. 3018-3028, 1999. 

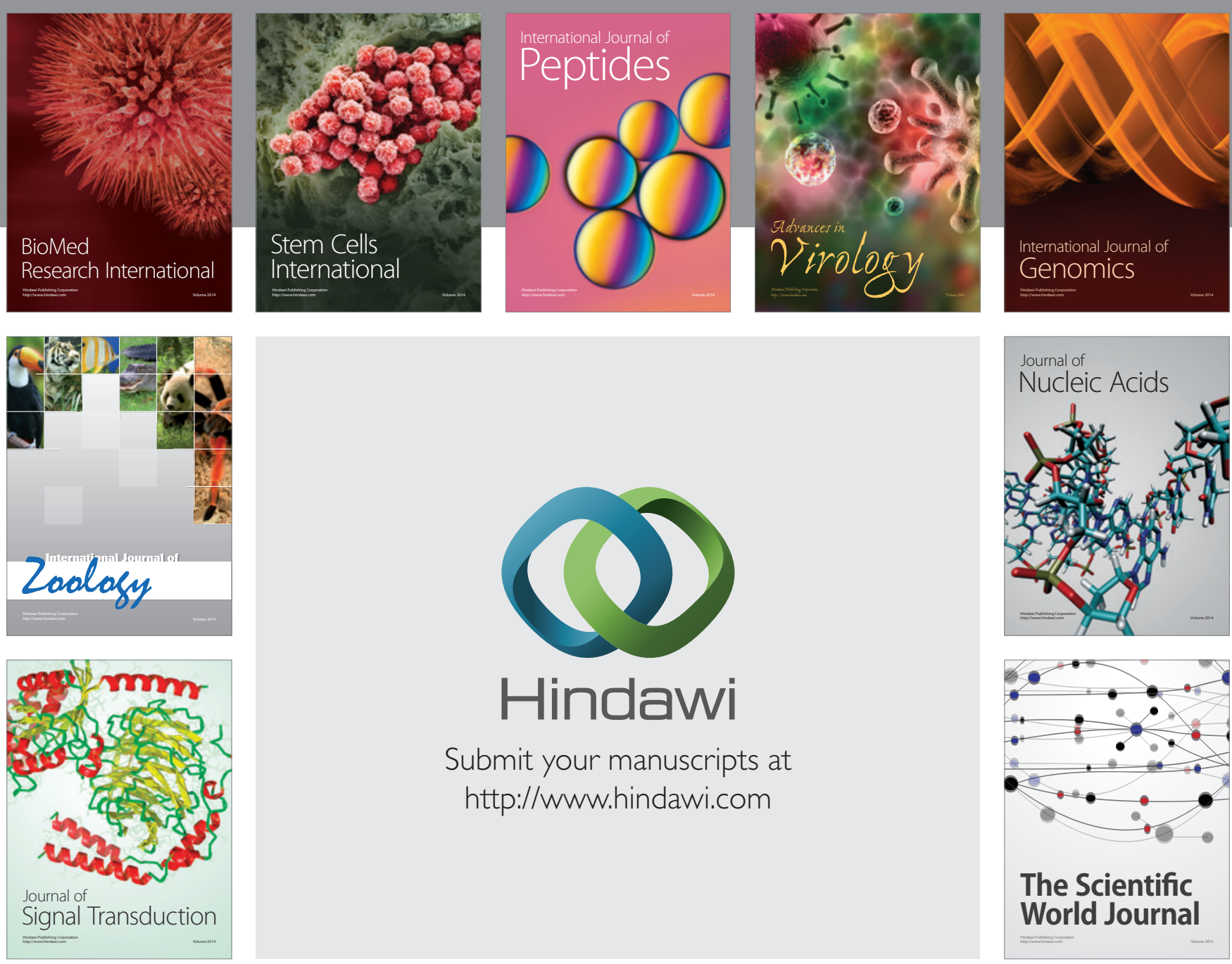

Submit your manuscripts at

http://www.hindawi.com
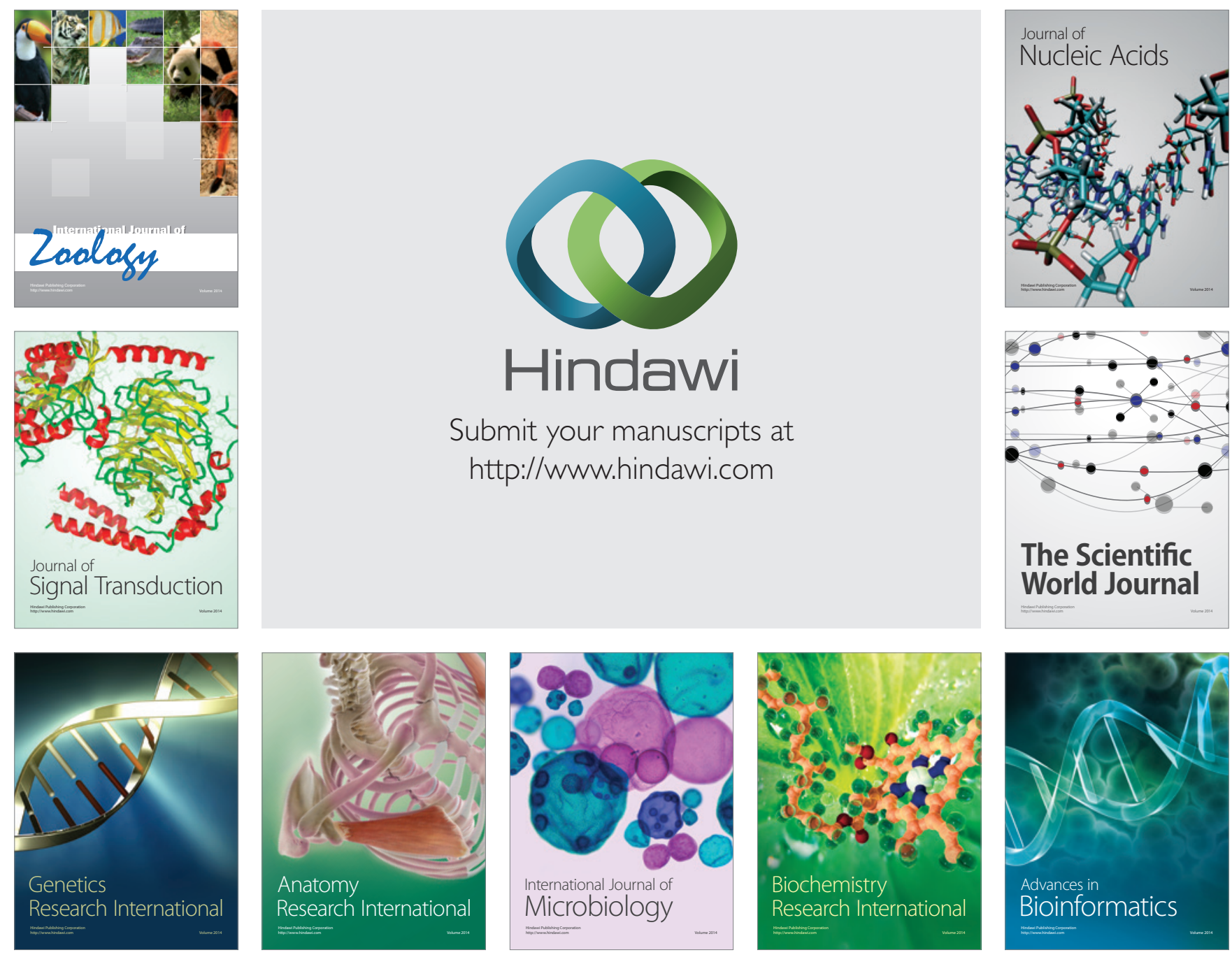

The Scientific World Journal
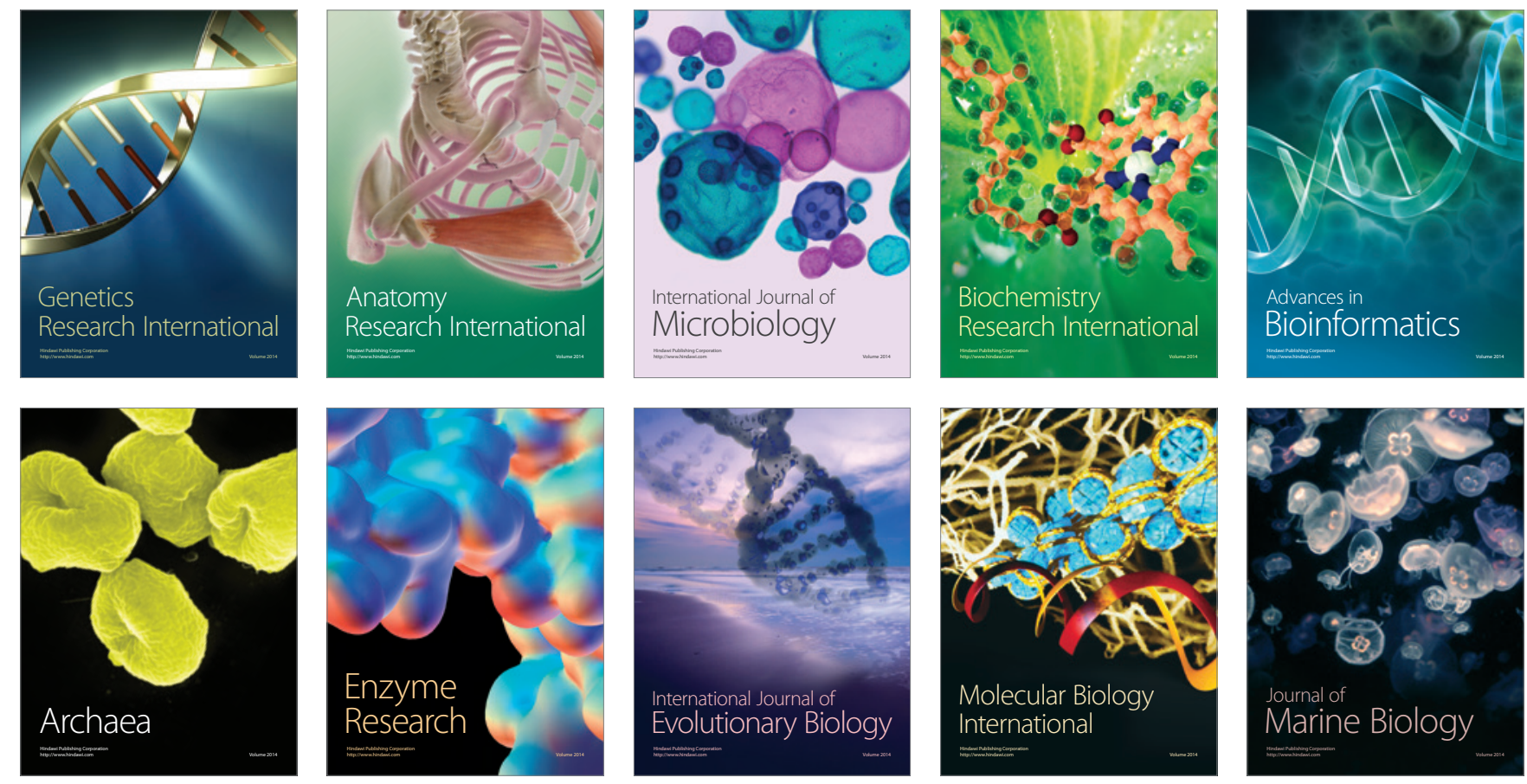